\title{
ANALISA FAKTOR-FAKTOR YANG MEMPENGARUHI TINGKAT \\ PERMINTAAN SUKUK RITEL-I \\ (Periode Maret 2009-Juni 2010)
}

\section{Oleh: Mohammad Agus Khoirul Wafa ${ }^{1}$}

\begin{abstract}
Abstrak
Sukuk has been popular topic of study among investors and researchers from 2009 until now. This study is aimed to oversee the correlation and the influence of banking deposit interestrates, the level of revenue sharing of banking deposits, Sukuk State Retailprice on the level of demand for state retail sukuk, and other bond prices to the level of demand of Islamic Retail Goverment Bond. The coherent time used in this study is data from March 2009 until June 2010. From the analysis of data using VAR methods, this study found that partially each independent variable has a significant effect on the level of demand for retail government sukuk. The result strengthens the hypothesis that jointly each independent variable has significant influence on the secondary market demand for sukuk. The sharia instruments have potential strength to affect the demand of retail sukuk bigger than the conventional ones.
\end{abstract}

Keywords: Islamic Retail Government bond, Islamic Investment, Islamic Investment Theory on Demand

\section{PENDAHULUAN}

\section{A. Latar Belakang}

Salah satu bentuk investasi yang sesuai dengan syariah Islam adalah pada efek syariah. Efek syariah tersebut mencakup saham syariah, obligasi syariah, reksadana syariah, kontrak investasi kolektif efek beragun asset syariah, dan surat berharga lainnya yang sesuai dengan prinsip Syariah. ${ }^{2}$ Dari konsep kelembagaan dalam ekonomi yang berkembang saat ini salah satunya adalah sukuk. Sukuk dipandang sebagai alternatif yang lebih baik dari pada berutang karena antara lain mengandung unsur kerja sama

${ }^{1}$ Penulis adalah alumni Prodi Ekonomi Islam FIAI UII, saat ini sedang melanjutkan studi S2 di Magister Ekonomi Keuangan FE UII dengan konsentrasi Ekonomi Keuangan Islam. Email: wafa.mars@gmail.com.

${ }^{2}$ Aziz Budi Setiawan. (2005). Perkembangan Pasar Modal Syariah. Surabaya: Majalah Hidayatullah, p. 30. 
investasi, berbagi resiko dan keterlibatan aset (proyek-riil) yang juga mendasari penerbitan sukuk. ${ }^{3}$

Indonesia sebagai salah satu negara dengan tingkat kekuatan fiskal yang rendah sangat membutuhkan sukuk negara untuk pembiayaan defisit anggaran. Dengan pendekatan matematik dapat disimpulkan bahwa perekonomian yang menerbitkan sukuk untuk pembiayaan defisit anggaran maupun proyek-proyek pemerintah akan memiliki potensi peningkatan fiscal sustainability dalam jangka panjang. Hal ini dikarenakan pembiayaan dengan instrument sukuk didasarkan pada underlying asset yang berimplikasi pada aktivitas ekonomi riil dan terbebas dari aspek spekulasi. ${ }^{4}$

Terkait dengan upaya pengembangan pasar modal syariah, hingga saat ini terdapat beberapa fatwa DSN-MUI yang berkaitan dengan industri pasar modal, diantaranya adalah Fatwa No. 5 tahun 2000 tentang Jual Beli Saham; No.20 tahun 2000 tentang Pedoman Pelaksanaan Investasi untuk Reksa Dana Syariah; no. 32 tahun 2002 tentang Obligasi Syariah; No. 33 tahun 2002 tentang Obligasi Syariah Mudharabah; No. 40 tahun 2003 tentang Pasar Modal dan Pedoman Umum Penerapan Prinsip Syariah di Bidang Pasar Modal; dan No. 41 tahun 2004 tentang Obligasi Syariah Ijarah.

Penerbitan obligasi dan sukuk korporasi mencapai $\mathrm{Rp} 28,308$ triliun, naik 144,92\% dibanding tahun 2008 sebesar Rp 11,558 triliun. Obligasi korporasitumbuh 157,31\% dan sukuk korporasi tumbuh $34,94 \%{ }^{5}$. Ada beberapa hal yang menjadi alasan masyarakat memilih sukuk. Sebagaimana yang dikatakan Alvi Wijaya selaku peneliti di Karim Business Consulting bahwa salah satu pemicunya adalah kerinduan kalangan pecinta produk syariah terhadap instrumen keuangan berbasis syariah. Selain itu, sukuk negara ritel juga diminati dilihat dari daya tarik resi yang ditawarkan, karena jika dibanding dengan obligasi ritel Indonesia dengan deposito yang return biasanya 10\%, maka sukuk lebih memberikan return sebesar $12 \%$ sesuai dengan perhitungan ijarah yang ada. ${ }^{6}$

Hal ini diperkuat dengan keunggulan spesifik investasi syariah yang terkait langsung dengan sektor ekonomi riil, karena konsep investasi syariah yang senantiasa selalu diterapkan adalah Economi 1 on 1 yang berarti 1 monetary investment unit should represent 1 real asset. ${ }^{7}$

${ }^{3}$ Khairunnisa Musari. (2009). Problem Pemerintah dan Kelembagaan Ekonomi di Negara Muslim: Menggagas Sukuk Sebagai Instrumen Fiskal dan Moneter di Indonesia. Simposium Nasional Ekonomi Islam IV. Yogyakarta: Kerjasama FE UII, IAEI, P3EI, dan Prodi Ekonomi Islam FIAI UII, Bab Sukuk, p. 56.

${ }^{4}$ Jaka Sriyana. (2009). Peranan Sukuk Negara Terhadap Peningkatan Fiscal Sustainability, Simposium Nasional Ekonomi Islam IV (Yogyakarta: Kerjasama FE UII, IAEI, P3EI, dan Prodi Ekonomi Islam FIAI UII, Bab Sukuk, p. 94

${ }^{5}$ Vibiznews.com diakses pada tanggal 2/2/2010

${ }^{6}$ www.inilah.com diakses pada tanggal 2/2/2010

${ }^{7}$ M. Gunawan Yasni. Sukuk Ritel Yang Paling Bersinar. Jakarta: Majalah Sharing, edisi Maret 2009), p. 18. 
Beberapa keuntungan sukuk dibanding dengan produk lainnya yang mempengaruhi minat investor dalam membeli sukuk ini adalah tergambar dalam tabel perbandingan berikut ${ }^{8}$ :

\section{Tabel 1 Perbandingan Instrumen Investasi}

\begin{tabular}{|c|c|c|c|c|}
\hline Perbandingan & Saham & $\begin{array}{c}\text { Reksadana } \\
\text { terproteksi }\end{array}$ & Deposito & $\begin{array}{c}\text { Sukuk negara } \\
\text { ritel }\end{array}$ \\
\hline $\begin{array}{c}\text { Bentuk return } \\
\text { investasi }\end{array}$ & Deviden & Kupon obligasi & Bunga & Imbal hasil \\
\hline $\begin{array}{c}\text { Kepastian } \\
\text { return }\end{array}$ & Tidak pasti & $\begin{array}{c}\text { Tergantung } \\
\text { harga obligasi }\end{array}$ & $\begin{array}{c}\text { Tergantung suku } \\
\text { bunga }\end{array}$ & Pasti \\
\hline $\begin{array}{c}\text { Besaran return } \\
\text { investasi }\end{array}$ & Tidak pasti & $9 \%-12 \%$ & $8 \%-13 \%$ & $12 \%$ \\
\hline $\begin{array}{c}\text { Pembagian } \\
\text { return investasi }\end{array}$ & Tidak pasti & Pasti & Tiga bulanan & Bulanan \\
\hline $\begin{array}{c}\text { Minimal } \\
\text { investasi }\end{array}$ & Rp. 10 juta & Rp. 1 juta & Rp. 1 juta & Rp. 5 juta \\
\hline $\begin{array}{c}\text { Potensi selisih } \\
\text { harga di pasar } \\
\text { sekunder }\end{array}$ & Ada & $\begin{array}{c}\text { Tidak } \\
\text { diperdagangkan }\end{array}$ & $\begin{array}{c}\text { Tidak } \\
\text { diperdagangkan }\end{array}$ & Ada \\
\hline $\begin{array}{c}\text { Masa jatuh } \\
\text { tempo }\end{array}$ & Tidak Ada & Ada & Ada & Ada \\
\hline $\begin{array}{c}\text { Jaminan } \\
\text { pemerintah }\end{array}$ & Tidak ada & Tidak ada & $\begin{array}{c}\text { Maksimal } 2 \\
\text { milyar }\end{array}$ & Ada \\
\hline
\end{tabular}

Sumber: PT. Ralliance Securities, diolah

Selain itu, ada faktor lain pula yang dianggap mempengaruhi permintaan sukuk di pasar keuangan Indonesia. Jika dianalisa dari periodesasi antara 2008 dan 2009 terdapat UU yang mengatur tentang Surat Berharga Syariah Negara (SBSN) dan beberapa aturan pemerintah dan menteri yang mendukung pada pelaksanaan SBSN maupun sukuk negera ritel. Undang-undang ini dibuat lantaran permintaan pihak asing dan juga lokal untuk menjamin bentuk transaksi sukuk atau obligasi syariah secara positif, sehingga menjamin investasi di dalamnya. Undang-undang tersebut terealisasi dengan diterbitkannya UU. No. 19 tentang SBSN pada tahun 2008. Faktor regulasi ini memiliki pengaruh cukup besar dalam memacu permintaan atas sukuk. Hal ini dibuktikan dengan besarnya arus perdagangan SBSN dan sukuk negara ritel maupun instrumen semisal pasca adanya beberapa aturan tersebut mengalami peningkatan sebagaimana telah disebutkan di atas.

Banyak potensi yang bisa dimanfaatkan dari diterbitkannya sukuk yang satu ini. Sigit Pramono dan Azis Setiawan dalam karya tulisnya memprediksikan bahwa dengan adanya instrumen sukuk ini dapat dijadikan sebagai sumber pembiayaan baru

8 ttp://www.sebi.ac.id/index.php?option=com_content\&task=view\&id=563\&Itemid $=46$ diakses pada tanggal 2/2/2010 
dalam percepatan perekonomian negara'. Sukuk merupakan salah satu alternatif untuk dapat memperoleh dana segar dari negara-negara Timur Tengah, yang merupakan negara-negara kaya penghasil minyak yang tergabung dalam Gulf Corporation Council (GCC) karena sesuai dengan prinsip-prinsip syariah. Sukuk kian menarik karena mampu merangkul investor syariah yang selama ini terpinggirkan tanpa membatasi diri terhadap para investor obligasi konvensional. Selain itu terpukulnya sistem ekonomi konvensional yang selama ini sering terpukul karena bubble yang terjadi membuat sukuk sebagai salah satu instrumen ekonomi syariah makin dilirik, bahkan oleh investor obligasi konvensional sekalipun ${ }^{10}$.

Sukuk negara ritel sebagaimana telah disebutkan di atas, menjadi alasan utama dijadikan sebagai lahan investasi para investor kecil karena nilai minimal pembelian relatif kecil yakni sebesar Rp. 5.000.000,-. Keuntungan ini ditambah dengan hasil sewa dari produk ini ${ }^{11}$ yang didapatkan pertahunnya dari pembelian sukuk ini yaitu pada awal terbitnya sebesar $12 \%$, lebih tinggi dari obligasi ritel Indonesia yang besar keuntungan bunganya hanya $10 \%$ pertahun.

Di Indonesia, pemerintah resmi menerbitkan sukuk negara ritel pada 25 Februari 2009 untuk mendukung APBN 2009. ${ }^{12}$ Jenis akad sukuk negara ritel yang akan diterbitkan adalah ijarah sale and lease back dengan underlying assets berupa barang milik negara berupa tanah dan/atau bangunan yang saat ini sedang digunakan oleh Depkeu. ${ }^{13}$ Sukuk negara ritel perdana yang diterbitkan memiliki tenor (jangka waktu) 3 tahun (jatuh tempo 25 Februari 2012) dengan nominal per unit Rp 1 juta dengan minimum pembelian sebesar Rp 5 juta dan kelipatannya serta tidak ada batas maksimum pembelian. Tingkat imbal hasil akan ditentukan satu hari sebelum tanggal penawaran. Imbal hasil sebesar $12 \%$ itu akan dibayarkan secara bulanan (tiap tanggal 25). Permintaan terhadap sukuk negara ritel I yang masuk mencapai $R p 5,56$ triliun. Permintaan ini $313,9 \%$ dari target awal pemerintah. ${ }^{14}$

Banyak faktor yang mempengaruhi pesatnya permintaan pada produk ini sebagai mana dikemukakan pada latar belakang penelitian ini. Sehingga peneliti dalam

9 Sigit Pramono dan Azis Setiawan. (2006). Obligasi Syariah (Sukuk) Untuk Pembiayaan Infrastruktur: Tantangan dan Inisiatif Strategis. Yogyakarta: Makalah Seminar dan Kolokium Perkembangan Sistem Keuangan Syariah.

${ }^{10}$ Nanda Sitepu, Sukuk; Definisi, Kondisi, dan Potensi?, Diakses dalam http:// www.vibiznews.com/column.php?sub=column\&id=1495\&page=bondsmutual pada 21 April 2010

${ }^{11}$ Sukuk yang menggunakan instrumen ijarah

${ }^{12} \mathrm{http}: / /$ www.sripoku.com/view/4102/Sukuk-Ritel-Terbit-25-Februari-html, website sriwijaya pos tanggal 7 januari 2009. diakses pada tanggal 23 juli 2010

${ }^{13}$ http://nasional.kompas.com/read/2009/01/07/13104029/Sukuk.Ritel.Terbit. 25.Februari, website kompas tanggal 7 januari 2009, diakses pada tanggal 23 juli 2010

${ }^{14}$ http://www.kontan.co.id/index.php/investasi/news/9047/Penjualan-Sukuk-Ritel-TigaKali-Target, website harian kontan tanggal 24 februari 2009, diakses pada tanggal 23 juli 2010 
hal ini mengukur tingkat signifikansi faktor-faktor tersebut dalam rumusan masalah sebagai bahan acuan untuk tindak lanjut maksimalisasi fungsi produk ini dalam pengadaan APBN ke depan melalui faktor-faktor yang ada. Penelitian ini akan menganalisa secara mendalam tentang perkembangan sukuk di pasar sekunder dan faktor-faktor yang mempengaruhi permintaan atas produk ini dengan basis pada penelitian terdahulu atas obligasi konvensional atau produk semisal yang telah diteliti terlebih dahulu oleh beberapa pakar ekonomi dan akademisi. Fokus penelitian ini dimaksudkan untuk memaksimalkan produk ini sehingga dapat digunakan sebagai instrumen pendukung pembangunan infrastruktur negara dengan analisa faktor-faktor yang mempengaruhinya.

\section{TINJAUAN PUSTAKA DAN LANDASAN TEORI}

\section{A. Tinjauan Pustaka}

Dari penelusuran literatur penelitian terdahulu terkait faktor-faktor yang mempengaruhi tingkat permintaan atas sukuk negara ritel belum ditemukan bentuk penelitian yang langsung membahas tentang ini karena memang sukuk negara ritel termasuk produk yang baru diterbitkan mulai dari awal tahun 2009. Hanya terdapat beberapa penelitian terkait tentang sukuk yang dapat digunakan sebagai acuan dasar dalam penelitian ini yang meneliti tentang pola faktor internal maupun eksternal terhadap harga obligasi syariah korporasi. Adapun penelitian tersebut adalah sebagai berikut:

Wahyu Widodo ${ }^{15}$ dalam penelitiannya yang menggunakan hipotesa pada variabel independen suku bunga sertifikat Bank Indonesia (SBI), tingkat bunga deposito, dan Produk Domestik Bruto antara tahun triwulan pertama 2002 sampai dengan tri wulan ke empat 2008, menghasilkan kesimpulan akhir bahwa kenaikan suku bunga SBI dan Suku bunga deposito berpengaruh negatif pada permintaan atas obligasi sehingga jika terjadi kenaikan suku bunga SBI dan Suku bunga Deposito menyebabkan permintaan atas obligasi menurun. Sedangkan variabel PDB dalam hal ini memberikan pengaruh positif pada kenaikan permintaan atas obligasi korporasi, dapat diartikan bahwa peningkatan atas PDB berpengaruh pada peningkatan atas permintaan obligasi korporasi.

Beberapa peneliti seperti Sudjono, Haryanto dan Riyanto serta Suhardi sebagaimana dikutip Wahyu Widodo mencoba mengetahui pengaruh suku bunga terhadap harga-harga instrumen pasar modal ${ }^{16}$. Ketiganya memperoleh kesimpulan yang sama mengenai pengaruh suku bunga SBI terhadap harga yang selanjutnya

${ }^{15}$ Wahyu Widodo. (2009), Faktor-Faktoryang Mempengarubi Permintaan Obligasi Korporasi di Indonesia. Skripsi Universitas Lampung, pp, 73-74.

${ }^{16}$ Wahyu Widodo, ibid., p.74. 
berpengaruh terhadap permintaan oleh masyarakat. Suku bunga SBI satu bulan merupakan benchmark atas penetapan suku bunga instrumen keuangan seperti suku bunga kredit dan simpanan. Pengaruh ini selanjutnya berpengaruh terhadap kemampuan perusahaan membayar kewajiban-kewajibannya atas seluruh surat berharga yang diterbitkannya serta harga relatif aset-aset tersebut terhadap harga aset keuangan lainnya.

Hasil penelitian Sudjono sebagaimana dikutip Wahyu Widodo yang juga menggunakan variabel bebas suku bunga deposito satu bulan sebagai salah satu faktor yang mempengaruhi permintaan aset pasar modal juga didukung oleh hasil penelitian ini. Sudjono memperoleh kesimpulan yang sama mengenai pengaruh suku bunga deposito satu bulan terhadap permintaan aet pasar modal. Menurutnya, tingkat suku bunga simpanan ini berpengaruh negatif terhadap harga dan selanjutnya berpengaruh terhadap permintaan aset pasar modal. Kenaikan suku bunga deposito satu bulan menyebabkan harga aset pasar modal turun relatif terhadap harga aset keuangan, dan sebagai akibatnya permintaan atas aset pasar modal menjadi menurun. Sebaliknyajika suku bunga deposito turun, harga untuk aset pasar modal meningkat relatif terhadap harga aset di pasar keuangan. Sebagai akibat perubahan ini, permintaan masyarakat terhadap aset pasar modal menjadi meningkat.

Amardin Amir ${ }^{17}$ dalam karyanya yang berjudul Pegarub Suku Bunga SBI, IHSG, Kurs, ROA dan Leg1 Harga Obligasi Terhadap Harga Obligasi Konvensional dan Syariah(Studi Kasus Obligasi PT. Bank Bukopin TBK tabun 2003)menyatakan bahwa dari faktor-faktor yang disebutkan dalam penelitian ini hanya variabel Kurs rupiah atas dolar yang berpengaruh signifikan dalam penciptaan harga baru pada obligasi syariah Bank Bukopin TBK di pasar sekunder dengan tingkat signifikansi 0.0279. Dari beberapa penelitian terdahulu tersebut di atas, secara spesifik belum dilakukan penelitian yang membahas tentang adanya pengaruh dari beberapa faktor tersebut di atas terhadap sukuk negara ritel. Oleh karena itu dalam penelitian ini penulis menganalisa beberapa faktor keuangan yang dapat mempengaruhi permintaan sukuk negara ritel di pasar sekunder. Hal ini menjadi sangat penting karena banyaknya ekspektasi dari perkembangan produk ini untuk pembanguan negara yang dalam hal ini melalui APBN.

\section{B. Landasan Teori}

\section{Sukuk Negara Ritel Negara}

Sukuk dalam Sharia Standard No.17 yang telah dikeluarkan oleh The Accounting and Auditing Organisation OfIslamic Financial Institutions (AAOIFI) tentang Investment sukuk didefinisikan sebagai berikut ${ }^{18}$ :

"Investment Sukuk are certificates of equal value representing undivided sharesin owerership of tangible assets, usufruct and services or (in the owemership of) the assets or particular

${ }^{17}$ Amardin Amir, op.cit., p.98.

${ }^{18}$ Burhanuddin, op.cit., p.58 
projects or special investment activity, however, this is true after receipt of the value of the sukuk, the closing of subcription and the employment of funds received for the purposefor which the sukuk were issued."

Investasi sukuk adalah sertifikat dengan nilai yang sama yang mewakili bagian kepemilikan yang sepenuhnya terhadap aset yang tangible, manfaat dan jasa atau (kepemilikan dari) aset dari suatu proyek atau aktivitas investasi khusus. Berdasarkan fatwa DSN-MUI Nomor 32/DSN-MUI/IX/2002 ${ }^{19}$, sukuk didefinisikan sebagai obligasi syari'ah, yaitu "surat berharga jangka panjang berdasarkan prinsip syariah yang dikeluarkan emiten kepada pemegang obligasi syariah yang mewajibkan emiten untuk membayar pendapatan kepada pemegang obligasi syariah berupa hasil/marginfee, serta membayar kembali dana obligasi saat jatuh tempo.”

Definisi lain sukuk atau obligasi syariah adalah "surat berharga sebagai instrumen investasi yang diterbitkan berdasar suau transaksi atau akad syariah yang melandasinya, yang dapat berupa ijarah, mudharabah, musyarakah atau yang lain.”20 Dalam Peraturan Menteri Keuangan dinyatakan bahwa Surat Berharga Syariah Negara (SBSN) Ritel atau Sukuk Negara Ritel (SNR) ini adalah SBSN yang dijual kepada individu atau orang perseorangan warga Negara Indonesia melalui agen penjual ${ }^{21}$. Dalam undang-undang yang telah terbit tahun 2008, SBSN diartikan sebagai surat berharga negara yang diterbitkan berdasarkan prinsip syariah, sebagai bukti atas bagian penyertaan terhadap Aset SBSN, baik dalam mata uang rupiah maupun valuta asing. ${ }^{22}$

Kamal Zubair dalam penelitiannya menyatakan bahwa sukuk pada prinsipnya mirip seperti obligasi ${ }^{23}$, dengan perbedaan pokok antara lain berupa penggunaan konsep imbalan dan bagi hasil sebagai pengganti bunga, adanya suatu transaksi pendukung (underlying transaction) berupa sejumlah tertentu aset yang menjadi dasar penerbitan, dan adanya akad atau penjanjian antara para pihak yang disusun berdasarkan prinsip-prinsip syariah. Transaksi sukuk bukan akad utang piutang melainkan penyertaan, karena surat hutang menimbulkan kesan adanya bunga yang menurut syariah tidak halal sehingga tidak boleh diterbitkan.

${ }^{19}$ Dewan Syariah Nasional MUI dan Bank Indonesia. (2003). Himpunan Fatwa Dewan Syariah Nasional; Edisi Kedua. Jakarta: PT. Intermasa

${ }^{20}$ Nasution, Mustafa Edwin et al. (2006). Pengenalan Ekslusif Ekonomi Islam. Cetakan Pertama. Jakarta: Kencana, hlm.304

${ }^{21}$ Peraturan Menteri Keuangan No. 218 Tahun 2008 Tentang Penerbitan dan Penjualan Surat Berharga Syariah Negara Ritel Di Pasar Perdana Dalam Negeri.

${ }^{22}$ UU No.19 Tahun 2008 tentang Surat Berharga Syariah Negara

${ }^{23}$ Kamal Zubair (2008) Instrumen Investasi Pasar Modal (Analisis Perbandingan Obligasi dan Sukuk), International Seminar and Symposiumon Implementation of Islamic Economics To Positive Economics in The World as Alternative of Conventional Economics System:Toward Development in The New Era of The Holistic Economics, (Surabaya: Unair, 1-2 Agustus 2008), p.23. 
Bentuk SNR ini adalah SBSN tanpa warkat (scripless)dan dapat diperdagangkan di pasar sekunder, dengan jenis akad Ijarah-Sale $E$ Lease Back ${ }^{24}$. SBSN ini diterbitkan khusus untuk investor ritel warga negara Indonesia, dengan pembatasan investasi untuk investor institusi di pasar perdana, sehingga untuk selanjutnya disebut dengan Sukuk Negara Ritel. Karakteristik Pokok SNR seri SR-001 ini adalah ${ }^{25}$ Ijarah-Sale E Lease Back dengan tanggal penerbitan 25 Februari 2009 dan Tanggal Jatuh Tempo 25 Februari 2012.

Nilai Nominal SNR yang akan diterbitkan akan ditetapkan oleh Pemerintah berdasarkan hasil pelaksanaan penjualan. Nilai Nominal per unit SNR ditetapkan sebesar Rp. 1.000.000,- (satu juta rupiah). Imbalan berupa sewa yang jumlah pembayarannya bersifat tetap (fixed-coupon). Imbalan/ kupon per unit SNR adalah sebesar $12 \%$ (dua belas per seratus) pertahun yang dibayar setiap bulan.

2. Teori Permintaan Barang dan Jasa

Dalam teori ekonomi tradisional ada beberapa faktor yang dapat mempengaruhi jumlah barang yang diminta oleh konsumen ${ }^{26}$, yaitu harga barang, harga barang lain yang berkaitan erat dengan barang tersebut, pendapatan RT dan pendapatan rata-rata masyarakat, corak distribusi pendapatan dalam masyarakat, cita rasa atau selera masyarakat, jumlah penduduk, dan ramalan keadaan di masa datang. Persamaan ini biasanya digambarkan dengan $X=f\left(P_{x}, P_{y}, P, M, S\right)$

\section{Teori Permintaan Pada Pasar Modal}

Mengacu pada teori permintaan dasar barang dan jasa, dalam pasar modal tingkat permintaan atas saham dipengaruhi oleh beberapa hal. Dari beberapa teori yang sudah umum dan merujuk pada teori permintaan umum barang atau jasa diketahui bahwa diantara faktor yang mempengaruhi tersebut adalah deviden, harga saham, harga saham lain, tingkat likuiditas, suku bunga SBI, pajak, deposito perbankan, dan preferensi.

Teori ini diperkuat dan ditambah beberapa faktor dengan beberapa penelitian seperti penelitian Nurul $\mathrm{Huda}^{27}$ bahwa beta saham dipengaruhi oleh Current Ratio, Leverage, dan Return of Equity. Sedangkan dalam obligasi dan produk semacamnya tingkat

${ }^{24}$ Peraturan Menteri Keuangan, ibid, pp. 3-4

${ }^{25}$ Peraturan Menteri Keuangan, ibid, p. 3

${ }^{26}$ Boediono (2002), Pengantar Ilmu Ekonomi, Yogyakarta: BPFE, p. 26

${ }^{27}$ Nurul Huda. (2004). Pasar Modal Syariah dan Faktor-Faktor Yang Mempengarubi Beta Saham (studi kasus JII dan LQ-45 tahun 2002-2003). Thesis S2 Jakarta: UI. 
permintaannya dalam hal ini harga dalam penelitian Rio Hartanto Syafirdi ${ }^{28}$ tentang pengaruh suku bunga, inflasi, kurs rupiah, indeks harga saham gabungan, kinerja perusahaan, dan likuiditas perusahaan terhadap harga obligasi syariah di pasar sekunder dengan studi kasus Obligasi Indosat Syariah Mudharabah 2002 menjelaskan bahwa variabel yang mempengaruhi harga obligasi syariah adalah kurs rupiah terhadap US dollar dan harga obligasi indosat syariah mudharabah 2002 pada waktu 1 bulan sebelumnya. Penelitian di atas diperkuat dengan penelitian setelahnya oleh Amardin Amir bahwa kurs rupiah terhadap dolar BEJ memiliki pengaruh yang signifikan terhadap obligasi syariah dengan tingkat signfikansi sebesar 0,0279.

Adapun faktor-faktor yang umum digunakan sebagai variabel yang mempengaruhi harga obligasi yang diambil dari berbagai penelitian terdahulu ${ }^{29}$ adalah suku bunga SBI, PDB, deposito perbankan, likuiditas emiten, harga obligasi, harga obligasi lain, dan preferensi.

\section{Kerangka dan Hipotesis Penelitian}

Berdasarkan penelitian terdahulu dan landasan teori yang digunakan di atas maka dapat dirumuskan kerangka pemikiran dalam penelitian ini dapat dibentuk hipotesis penelitian dengan persamaan hipotesis null sebagai berikut:

a. Harga sukuk negara ritel tidak mempunyai pengaruh negatif yang signifikan terhadap permintaan atas sukuk negara ritel

b. Harga obligasi ritel tidak mempunyai pengaruh positif yang signifikan terhadap permintaan atas sukuk negara ritel

c. Tingkat bagi hasil deposito satu bulan bank syariah tidak mempunyai pengaruh negatif yang signifikan terhadap permintaan atas sukuk negara ritel

d. Tingkat suku bunga tidak mempunyai pengaruh negatif yang signifikan terhadap permintaan atas sukuk negara ritel

\section{METODE PENELITIAN}

\section{A. Jenis Penelitian}

Penelitian ini menggunakan bentuk penelitian deskriptif kuantitatif. Metode deskriptif yaitu metode yang didsarkan pada analisis dengan pendeskripsian faktorfaktor yang berhubungan dengan masalah yang dimaksudkan sebagai pendukung untuk

${ }^{28}$ Rio Hartanto Syafirdi. (2006) “Pengarub Suku Bunga, Inflasi, Kurs Rupiah, Indeks Harga Saham Gabungan, Knerja Perusahaan dan Likuiditas Perusahaan terhadap Harga Obligasi Syariah di Pasar Sekunder (Studi Kasus: Obligasi Indosat Syariah Mudharabah 2002)", Tesis Universitas Indonesia, p. 81

${ }^{29}$ Amardin Amir (2007), Sudjono (2002), dan Wahyu Widodo (2009), op.cit. 
analisis metode kuantitatif. Sedangkan metode kuantitatif adalah penelitian yang dilakukan untuk mencari berbagai variabel yang menjadi objek penelitian. ${ }^{30}$ Sedangkan muara penelitian ini adalah penelitian pustaka.

\section{B. Objek Penelitian}

Objek penelitian ini adalah instrumen sukuk negara ritel yang mulai diterbitkan di pasar perdana dengan penghitungan awal setelah masuk pada pasar sekunder atau dalam Bursa Efek Indonesia (BEI) yang dimulai pada bulan Maret 2009 sampai dengan akhir Juni 2010.

\section{Data dan Sumber Data}

Data yang digunakan dalam penelitian ini berupa data sekunder (secondary data) yaitu data yang diperoleh dari pihak kedua ${ }^{31}$, yang berupa laporan perkembangan secara nominal maupun prosentase dari setiap variabel bebas dan terikat yang telah ditentukan dalam hipotesis. Data tersebut diperoleh dari:

1. Data statistik Suku Bunga Deposito Bank Umum (Konvensional), dan Bagi Hasil Perbankan Syariah dapat diperoleh dari data induk statistik perbankan pada Bank Indonesia (www.bi.go.id).

2. Data Statistik Investasi dan harga Obligasi dapat diperoleh dari data statistik Bapepam dan Lembaga Keuangan (www.bapepam.go.id) dan .Lembaga Kajian Obligasi yakni Indonesia Bond Pricing Agency (www.ibpa.co.id), Indonesia Stock Exchange (www.idx.co.id), dan Jurnal atau publikasi lain yang memuat informasi yang relevan dengan penelitian.

\section{Definisi Operasional Variabel}

Variabel atau dalam bahasa inggris dengan tulisan variabel berarti faktor tak tetap atau berubah-ubah. Namun bahasa Indonesia kontemporer telah terbuasa menggunakan kata variabel ini dengan pengertian yang lebih tepat disebut bervariasi. Dengan demikian variabel adalah fenomena yang berbariasii dalam bentuk, kualitas, kuantitas, mutu standar, dan sebagainya ${ }^{32}$.

Secara umum variabel dalam penelitian ini terbagi menjadi dua. Variabel dependen (tergantung) dan variabel independen (bebas).

\section{Variabel dependen}

Variabel dependen dalam penelitian ini adalah tingkat permintaan investor atas sukuk negara ritel. Sukuk negara ritel sebagaimana telah dijelaskan dalam kajian teori merupakan salah satu instrumen investasi di pasar modal Indo-

\footnotetext{
${ }^{30}$ M. Burhan Bungin (2005) Metode Penelitian Kuantitatif(Jakarta: Prenada Media), p. 49

${ }^{31}$ Ibid, p. 54

32 ibid, p.59.
} 
nesia dengan prinsip syariah. Dalam penelitian ini variabel sukuk negara ritel ini memiliki satuan volume yaitu miliar.

\section{Variabel bebas (independen)}

a. Harga Sukuk Negara Ritel (SNR)

Secara umum harga sukuk negara ritel merupakan nilai jual dari SNR yang naik turunnnya dihitung pada setiap akhir transaksinya setiap hari aktif transaksi pada pasar sekunder dengan perhitungan indeks.

b. Tingkat Suku Bunga Deposito Perbankan,

Suku bunga adalah harga dana yang dapat dipinjamkan (loanablefunds), besarnya ditentukan oleh preferensi dan sumber pinjaman berbagai pelaku ekonomi. Suku bunga tidak hanya dipengaruhi perubahan preferensi para pelaku ekonomi, dalam hal pinjaman dan pemberian pinjaman, tetapi dipengaruhi perubahan daya beli uang, hal ini disebabkan karena suku bunga pasar atau suku bunga yang berlaku berubah dari waktu ke waktu dan suku bunga kapan dari kebanyakan obligasi jangka panjang ditetapkan pada waktu penerbitannya, maka harga saham berubah-ubah sesuai dengan perubahan suku bunga.

c. Nisbah Bagi Hasil deposito Perbankan Syariah,

Nisbah Bagi hasil deposito perbankan syariah adalah prosentase keuntungan yang diberikan perbankan kepada nasabah yang digunakan untuk menentukan besaran bagi hasil dari keuntungan yang diperoleh perbankan syariah antara nasabah pengguna jasa dan bank syariah.

d. Harga obligasi lain.

Secara umum harga obligasi lain dalam penelitian ini mengacu pada harga ORIO03 yang merupakan nilai jual dari ORIO03 yang naik turunnnya dihitung pada setiap akhir transaksinya setiap hari aktif transaksi pada pasar sekunder dengan perhitungan indeks.

\section{E. Metode Analisis}

Metode analisis yang digunakan dalam penelitian ini adalah analisis regresi data time series. Adapun prosedur analisis data adalah sebagai berikut:

1. Analisis Normalitas Data

2. Analisis Stationaritas Data

3. Analisis Kointegrasi data

4. Analisis dan Estimasi Vector Autoregression

Model persamaan biasanya menggunakan teori ekonomi untuk menggambarkan hubungan antara variabel yang terkait. Hasil dari model kemudian diestimasi dan digunakan untuk menguji relevansi empiris dari teori tersebut. Sayangnya teori ekonomi mungkin tidak cukup untuk menentukan spesifikasi yang benar. Hal ini disebabkan karena mungkin teorinya terlalu rumit sehingga sulit bagi kita untuk menurunkan spesifikasi secara persis. Atau mungkin saja teorinya adalah sesuai dengan 
struktur selang yang dibangun tetapi struktur-struktur selang ini dapat menghasilkan model dengan perilaku dinamis yang berbeda.

Model mengganggap bahwa semua variabel ekonomi adalah saling tergantung dengan yang lain. Model teoritis yang digunakan dalam penelitian ini adalah:

$$
\begin{aligned}
& Y_{1 \mathrm{t}}=\alpha_{1}+\sum \beta_{1 \mathrm{j}} \mathrm{Y}_{1 \mathrm{t}-\mathrm{j}}+\sum \lambda_{1 \mathrm{j}} \mathrm{Y}_{2 \mathrm{t}-\mathrm{j}}+\sum \gamma_{1 \mathrm{j}} \mathrm{Y}_{3 \mathrm{t}-\mathrm{j}}+\sum \omega_{1 \mathrm{j}} \mathrm{Y}_{4 \mathrm{t}-\mathrm{j}}+\varepsilon_{1} \\
& \mathrm{Y}_{2 \mathrm{t}}=\alpha_{2}+\sum \beta_{2 \mathrm{j}} \mathrm{Y}_{2 \mathrm{t}-\mathrm{j}}+\sum \lambda_{2 \mathrm{j}} \mathrm{Y}_{1 \mathrm{t}-\mathrm{j}}+\sum \gamma_{2 \mathrm{j}} \mathrm{Y}_{3 \mathrm{t}-\mathrm{j}}+\sum \omega_{2 \mathrm{j}} \mathrm{Y}_{4 \mathrm{t}-\mathrm{j}}+\varepsilon_{2} \\
& \mathrm{Y}_{3 \mathrm{t}}=\alpha_{3}-\sum \beta_{3 \mathrm{j}} \mathrm{Y}_{3 \mathrm{t}-\mathrm{j}}+\sum \lambda_{3 \mathrm{j}} \mathrm{Y}_{1 \mathrm{t}-\mathrm{j}}+\sum \gamma_{3 \mathrm{j}} \mathrm{Y}_{3 \mathrm{t}-\mathrm{j}}+\sum \omega_{3 \mathrm{j}} \mathrm{Y}_{4 \mathrm{t}-\mathrm{j}}-\varepsilon_{3} \\
& \mathrm{Y}_{4 \mathrm{t}}=\alpha_{4}+\sum \beta_{4 \mathrm{j}} \mathrm{Y}_{4 \mathrm{t}-\mathrm{j}}+\sum \lambda_{4 \mathrm{j}} \mathrm{Y}_{1 \mathrm{t}-\mathrm{j}}+\sum \gamma_{4 \mathrm{j}} \mathrm{Y}_{2 \mathrm{t}-\mathrm{j}}+\sum \omega_{4 \mathrm{j}} \mathrm{Y}_{3 \mathrm{t}-\mathrm{j}}-\varepsilon_{4} \\
& \mathrm{Y}_{5 \mathrm{t}}=\alpha_{5}+\sum \beta 5 \mathrm{Y}_{5 \mathrm{t}-\mathrm{j}}+\sum \lambda_{5 \mathrm{j}} \mathrm{Y}_{1 \mathrm{t}-\mathrm{j}}+\sum \gamma_{5 \mathrm{j}} \mathrm{Y}_{3 \mathrm{t}-\mathrm{j}}+\sum \omega_{5 \mathrm{j}} \mathrm{Y}_{4 \mathrm{t}-\mathrm{j}}+\varepsilon_{5}
\end{aligned}
$$

dengan

$\begin{array}{lll}\mathrm{Y}_{1}: & \quad \text { Volume Permintaan Sukuk Negara Ritel (Vol) } \\ \mathrm{Y}_{2}: & \text { Harga Indeksasi Sukuk Negara Ritel(IS) } \\ \mathrm{Y}_{3}: & \text { Harga Indeksasi Obligasi Ritel (IO) } \\ \mathrm{Y}_{4}: & \text { Tingkat Bagi Hasil Deposito 1 bulan Bank Syariah(TS) } \\ \mathrm{Y}_{5}: & \text { Tingkat Suku Bunga Deposito 1 bulan Bank Umum(TU) } \\ \mathrm{e}_{\mathrm{i}}: & \text { error dengan } \mathrm{i}=1,2,3,4,5 \\ \mathrm{j}: & \text { panjang lag dengan } \mathrm{j}=1,2, \ldots, \mathrm{k} \\ \mathrm{k}: & \text { maksimum panjang lag. }\end{array}$

Dari model teoritis tersebut, dibentuk model Vector Autoregressive orderp dinotasikan dengan $\operatorname{VAR}(p)^{[10]}$ :

$$
\begin{aligned}
& \mathrm{z}_{\mathrm{t}}=\mathrm{a}_{0}+\mathrm{f}_{1} \mathrm{z}_{\mathrm{t}-1}+\mathrm{f}_{2} \mathrm{z}_{\mathrm{t}-2}+\ldots \\
& +\mathrm{f}_{\mathrm{p}} \mathrm{z}_{\mathrm{t}-\mathrm{p}}+\mathrm{e}_{\mathrm{t}}
\end{aligned}
$$

\section{ANALISIS DATA DAN PEMBAHASAN}

Penelitian ini bertujuan untuk mengetahui apakah variabel dependen (permintaan atas sukuk negara ritel yang diwakili volume permintaan-vol-) dipengaruhi oleh empat variabel independent (harga sukuk negara ritel yang diwakili dengan data indeks sukuk negara ritel-IS-, harga obligasi ritel lain dengan padanan indeks obligasi ritel-IO-, tingkat suku bunga deposito satu bulan bank umum-TU-, dan tingkat bagi hasil deposito satu bulan pada bank syariah-TS-). Dalam bab ini penulis menyajikan hasil dari analisis data berdasarkan pengamatan terhadap beberapa variabel yang dipakai dalam model regresi berganda. Populasi dalam penelitian ini adalah seluruh data terkait dengan variabel tersebut di atas selama periode Maret 2009 sampai dengan Juni 2010. 


\section{A. Analisis Deskriptif}

Berikut ini deskripsi data mengenai nilai minimum, maksimum, rata-rata serta standar deviasi untuk tiap-tiap variabel selama periode penelitian Juni 2009 sampai Mei 2010. Dari hasil analisis deskriptif dapat diketahui bahwa variabel volume permintaan selama periode penelitian memiliki nilai minimum sebesar 4.930000 yang artinya bahwa permintaan terendah sukuk sebesar 4.93 miliar rupiah dalam satu kali transaksi. Sedangkan nilai maksimumnya sebesar 22.97 miliar rupiah dalam satu kali transaksi. Sedangkan standar deviasi sebesar 6.363476 yang artinya selama satu periode penelitian, ukuran penyebaran dari variabel permintaan sukuk sebesar 6.602859 dari 16 kasus yang terjadi.

Pada variabel indeks sukuk (IS) nilai minimum selama periode penelitian sebesar 100 yang artinya bahwa harga minimum terletak pada indeks 100.0000 dalam satu kali transaksi. Sedangkan nilai maksimumnya sebesar 106.7250 dalam satu kali transaksi. Sedangkan standar deviasi sebesar 2.211202 yang artinya selama satu periode penelitian, ukuran penyebaran dari variabel indeks sukuk sebesar 2.211202 dari 16 kasus yang terjadi. Pada variabel indeks obligasi ritel (IO) selama periode penelitian memiliki nilai minimum sebesar 94.75000 yang artinya bahwa harga minimum terletak pada indeks 94.75000 dalam satu kali transaksi. Sedangkan nilai maksimumnya sebesar 102.7500 dalam satu kali transaksi. Sedangkan standar deviasi sebesar 2.389748 yang artinya selama satu periode penelitian, ukuran penyebaran dari variabel indeks obligasi sebesar 2.389748 dari 16 kasus yang terjadi.

Pada variabel tingkat bagi hasil deposito satu bulan bank syariah (TS) nilai minimum selama periode penelitian sebesar 5.840000 yang artinya bahwa prosentasi minimum bagi hasil yang diberikan bank syariah pada instrumen dana pihak ke tiga dari deposito satu bulan sebesar $5.84 \%$. Sedangkan nilai maksimumnya sebesar 9.130000 pada masa penelitian ini. Sedangkan standar deviasi sebesar 0.798179 yang artinya selama satu periode penelitian, ukuran penyebaran dari variabel tingkat bagi hasil bank syariah sebesar 0.798179 dari 16 kasus yang terjadi.

Pada variabel tingkat suku bunga deposito satu bulan bank umum (TU) nilai minimum selama periode penelitian sebesar 5.600000 yang artinya bahwa prosentasi minimum suku bunga yang diberikan bank umum pada instrumen dana pihak ke tiga dari deposito satu bulan sebesar 5.6\%. Sedangkan nilai maksimumnya sebesar 9.250000 pada masa penelitian ini. Sedangkan standar deviasi sebesar 1.246218 yang artinya selama satu periode penelitian, ukuran penyebaran dari variabel tingkat suku bunga bank umum sebesar 1.246218 dari 16 kasus yang terjadi.

\section{B. Uji Normalitas Data}

Dari uji normalitas dengan uji statistik JB didapatkan bahwa nilai statistiknya sebesar 1.678210 dengan probabalitasnya sebesar 43.2\%. Hasil uji ini menyatakan 
bahwa nilai statistik JB cukup besar dengan nilai probabilitas cukup besar, oleh karena itu dinyatakan bahwa residual yang didistribusikan dari tiap variabel mempunyai distribusi normal.

\section{Uji Stationeritas Data}

Sebagaimana dijelaskan dalam metode penelitian. Uji stationeritas data dalam penelitian menggunakan uji akar unit. Dengan bantuan eviews dapat diketahui bahwa hanya variabel volume permintaan sukuk Negara ritel dan indeks harga sukuk Negara ritel yang stationer pada tingkat level atau 0 . VOL stationer pada tingkat kepercayaan 99\% dan IS stationer pada tingkat kepercayaan 90\%. Sedangkan ketiga variabel lainnya stationer pada tingkat diferensi. Indeks harga obligasi ritel stationer pada tingkat diferensi 1 dengan tingkat kepercayaan 99\%, tingkat bagi hasil deposito bank syariah stationer pada tingkat diferensi 1 dengan tingkat kepercayaan 99\%, dan tingkat suku bunga deposito bank umum stationer pada tingkat diferensi 2 dengan tingkat kepercayaan $99 \%$.

\section{Uji Kointegrasi Data}

Dari hasil uji kointegrasi data di atas, dapat kita ketahui bahwa setiap variabel yang digunakan dalam penelitian ini memiliki nilai tau statistik lebih kecil dibanding dengan nilai z statistik/ tabel yang ada. Dengan ini dapat disimpulkan bahwa Ho diterima yang berarti tidak terdapat kointegrasi antar variabel dalam penelitian.

\section{E. Estimasi VAR}

Dari hasil perhitungan dengan lag 2, disimpulkan bahwa dengan mengamati $\mathrm{t}$ statistic dari masing-masing koefisioen, terdapat hubungan timbal balik antar variable kecuali volume permintaan atas sukuk dinyatakan signifikan dengan nilai t statistic koefisiean dari masing-masing variabel $\mathrm{vol}=0.66713, \mathrm{IS}=5.29514, \mathrm{IO}=-51.1692$, $\mathrm{TS}=5.46840$, dan $\mathrm{TU}=15.1306$ dimana VOL lebih rendah dari t tabel dengan df 4 dan alpha $5 \%$ sebesar 2,132.

Berdasarkan uji t, nilai t hitung tiap variabel pada persamaan IS, IO, TS, dan TU ada beberapa variabel yang signifikan terhadap volume permintaan atas sukuk (VOL) dengan tingkat kepercayaan sebesar 95\% diperoleh nilai t tabel sebesar 2,132.

Sedangkan persamaan variabel volume permintaan sukuk dalam uji ini tidak menunjukkan signifikansi. Hal ini menunjukkan bahwa hipotesis yang dibangun dalam penelitian benar karena hubungan variabel independen atas variabel dependen berpengaruh signifikan pada tingkat kelambanan tertentu, sehingga dapat disimpulkan dari uji t yang ada bahwa hipotesis alternatif dalam uji t ini diterima dengan melihat tingkat signifikansi pengaruh setiap variabel independent yang cukup tinggi terhadap variabel dependen. 
Berdasarkan uji $\mathrm{F}$ untuk menandakan hubungan dan pengaruh persamaan IS 7.451585, IO 529.6509, TS 37.86745, dan TU 376.0392 signifikan, sedangkan pada persamaan VOL 0.231086 tidak signifikan. Hal ini memperkuat hipotesis bahwa secara bersama-sama setiap variabel independen yang ada mempengaruhi signifikan permintaan sukuk pada pasar sekunder.

Berdasarkan hasil dari estimasi di atas dari nilai $R$ square yang ada dapat dikatakan setiap variabel independen (harga sukuk, harga obligasi ritel, tingkat bagi hasil deposito, dan tingkat suku bunga) dapat menjelaskan pengaruhnya dari faktorfaktor lainnya sebesar 0.986758 untuk harga sukuk, harga obligasi ritel sebesar 0.999811, tingkat bagi hasil sebesar 0.997366, dan tingkat suku bunga sebesar 0.999734 .

\section{F. Interpretasi Ekonomi}

Dari hasil olah data di atas kita dapat mengetahui pengaruh setiap variabel independen yang ada atas variabel dependen dengan melihat hasil t koefisien tiap variabel. Adapun interpretasinya adalah sebagai berikut:

1. Apabila terjadi perubahan satu persen pada indeks harga sukuk maka akan berpengaruh atas perubahan permintaan sukuk tersebut sekitar 1.128.584 lembar sukuk.

2. Apabila terjadi perubahan satu persen pada indeks harga obligasi ritel maka akan berpengaruh pada perubahan permintaan sukuk sekitar -3.027.561 lembar sukuk.

3. Apabila terjadi perubahan satu persen pada tingkat bagi hasil deposito bank syariah, maka akan berpengaruh atas perubahan pemintaan sukuk sekitar 1.668.395 lembar sukuk.

4. Apabila terjadi perubahan satu persen pada tingkat suku bunga deposito bank umum, maka akan berpengaruh atas perubahan pemintaan sukuk sekitar 1.272.057 lembar sukuk.

Dilihat dari segi perilaku investasi syariahnya, kita dapat melihat dari perubahan yang ada bahwa faktor-faktor yang non-syariah seperti halnya nilai pada obligasi ritel dan tingkat suku bunga bank umum pada dasarnya tidak berpengaruh secara signifikan terhadap pertimbangan perubahan permintaan sukuk Negara ritel. Dari asumsi tersebut dapat dilihat bahwa tingkat perubahan sepertihalnya pada instrumen investasi non syariah pada perubahan harga obligasi ritel lain berpengaruh sekitar -3.027.561 lembar sukuk terhadap permintaan sukuk dan perubahan variabel tingkat suku bunga deposito bank umum berpengaruh sekitar 1.272.057 lembar sukuk terhadap permintaan sukuk.

Jika dibandingkan dengan perubahan yang ada pada tingkat bagi hasil bank syariah dan nilai sukuk tersebut, dapat kita simpulkan bahwa perubahan pada instrumen syariah ini lebih besar pengaruhnya dari pada instrumen investasi yang masuk dalam kategori non-syariah atau konvensional dengan nilai perubahan dari harga sukuk Negara ritel berpengaruh sekitar 1.128.584 lembar sukuk terhadap permintaan sukuk dan 
tingkat bagi hasil deposito bank syariah berpengaruh sekitar 1.668.395 lembar sukuk terhadap permintaan sukuk.

\section{KESIMPULAN DAN SARAN}

\section{A. Kesimpulan}

Bentuk penelitian dalam pembahasan ini cukup memiliki komplikasi data time series yang rumit sehingga dengan berbagai pertimbangan model yang ada maka pada akhir uji coba pengolahan data dipilih model regresi Vector Autoregressive dalam bentuk difference untuk mengestimasi berbagai kemungkinan yang ada dalam penelitian ini.

Berdasarkan hasil analisis dan pembahasan yang telah dijelaskan dalam bab sebelumnya, maka dalam penelitian ini dapat diambil beberapa kesimpulan berikut:

1. Secara bersama-sama faktor independen yang terdiri dari harga sukuk negara ritel, harga obligasi ritel, tingkat bagi hasil deposito bank syariah, dan tingkat suku bunga mempunyai pengaruh yang signifikan terhadap tingkat permintaan sukuk negara ritel pada periode Maret 2009-Juni 2010.

2. Secara parsial setiap variabel independen di atas mempunyai pengaruh secara signifikan terhadap tingkat permintaan sukuk negara ritel periode Maret 2009Juni 2010.

3. Dari segi perilaku investasi secara syariah, instrumen-instrumen investasi syariah yang diajukan dalam penelitian ini memiliki bobot yang lebih tinggi pengaruhnya pada pertimbangan perubahan permintaan sukuk dibandingkan dengan investasi pada instrumen investasi konvensional.

\section{B. Saran}

Untuk kepentingan penelitian selanjutnya, diperlukan penelitian lebih lanjut dengan penambahan data dengan runtut waktu yang lebih lama agar penelitian ini dapat dimaksimalkan, sehingga hasilnya lebih mendukung keputusan kebijakan investasi.

\section{DAFTAR PUSTAKA}

Boediono (2002), Pengantar Ilmu Ekonomi, Yogyakarta: BPFE.

Bungin, M. Burhan (2005), Metode Penelitian Kuantitatif, Jakarta: Prenada Media.

Dewan Syariah Nasional MUI dan Bank Indonesia (2003), Himpunan Fatwa Dewan Syariah Nasional; Edisi Kedua, Jakarta: PT. Intermasa.

http://nasional.kompas.com/read/2009/01/07/13104029/Sukuk.Ritel. Terbit.25.Februari, website kompas tanggal 7 Januari 2009, diakses pada tanggal 23 Juli 2010 
http://www.kontan.co.id/index.php/investasi/news/9047/Penjualan-Sukuk-RitelTiga-Kali-Target, website harian kontan tanggal 24 Februari 2009, diakses pada tanggal 23 juli 2010

http://www.sebi.ac.id/index.php?option =com_content\&task $=$ view\&id $=563 \&$ Itemid $=46$ diakses pada tanggal $2 / 2 / 2010$

http://www.sripoku.com/view/4102/Sukuk-Ritel-Terbit-25-Februari-html, website Sriwijaya Pos tanggal 7 januari 2009. diakses pada tanggal 23 juli 2010

Huda, Nurul (2004), "Pasar Modal Syariah dan Faktor-Faktor Yang Mempengarubi Beta Sabam (Studi Kasus JII dan LQ-45 tabun 2002-2003)", Tesis Universitas Indonesia. Tidak dipublikasikan.

Musari, Khairunnisa (2009), "Problem Pemerintab dan Kelembagaan Ekonomi di Negara Muslim: Menggagas Sukuk Sebagai Instrumen Fiskal dan Moneter di Indonesia”, Paper Simposium Nasional Ekonomi Islam IV. Yogyakarta: FE UII, IAEI, P3EI, dan Prodi Ekonomi Islam FIAI UII.

Nanda, Sitepu (2010), “Sukuk; Definisi, Kondisi, dan Potensi?”, dikutip dari http:// www.vibiznews.com/column.php?sub= column\&id =1495\&page $=$ bondsmutual diakses 21 April 2010.

Nasution, Mustafa Edwin. et al. (2006), Pengenalan EkslusifEkonomi Islam, Cetakan Pertama, Jakarta: Kencana

Peraturan Menteri Keuangan No. 218 Tahun 2008 Tentang Penerbitan dan Penjualan Surat Berharga Syariah Negara Ritel di Pasar Perdana Dalam Negeri.

Pramono, Sigit, dan Setiawan, Azis (2006), “Obligasi Syariah(Sukuk) UntukPembiayaan Infrastruktur: Tantangan dan Inisiatif Strategis", Makalah Seminar dan Kolokium Perkembangan Sistem Keuangan Syariah.

Syafirdi, Rio Hartanto (2006), "Pengarub Suku Bunga, Inflasi, Kurs Rupiah, Indeks Harga Saham Gabungan, Kinerja Perusahaan, dan LikuiditasPerusabaan terhadap Harga Obligasi Syariah di Pasar Sekunder(Studi Kasus Obligasi Indosat Syariah Mudharabah 2002), Tesis Universitas Indonesia. Tidak dipublikasikan.

Setiawan, Aziz Budi (2005), Perkembangan Pasar Modal Syariah, Surabaya: Majalah Hidayatullah.

Sriyana, Jaka (2009) “Peranan Sukuk Negara Terhadap Peningkatan Fiscal Sustainability”, Paper Simposium Nasional Ekonomi Islam IV. Yogyakarta: FE UII, IAEI, P3EI, dan Prodi Ekonomi Islam FIAI UII

UU No.19 Tahun 2008 tentang Surat Berharga Syariah Negara.

Vibiznews.com diakses pada tanggal 2/2/2010

Widodo, Wahyu (2009), "Faktor-Faktor YangMempengarubi Permintaan ObligasiKorporasi diIndonesia”, Skripsi Universitas Lampung. Tidak dipublikasikan. 
Mohammad Agus Khoirul Wafa: Analisa Faktor-Faktor ...

www.inilah.com diakses pada tanggal 2/2/2010

Yasni, M. Gunawan, “Sukuk Ritel Yang Paling Bersinar”, Majalab Sharing, Maret 2009).

Zubair, Kamal. (2008), "Instrumen Investasi Pasar Modal (Analisis Perbandingan Obligasi dan Sukuk)", Paper International Seminar and Symposium on Implementation of Islamic Economics To Positive Economics in The World as Alternative of Conventional Economics System: Toward Development in The New Era of The Holistic Economics. Surabaya: Unair, 1-2 Agustus 2008. 